\title{
Hand Digit 1
}

National Cancer Institute

\section{Source}

National Cancer Institute. Hand Digit 1. NCI Thesaurus. Code C52834.

The thick and short hand digit which is next to the index finger in humans. 